\title{
PEMBENTUKAN KARAKTER DISIPLIN ANAK USIA DINI MELALUI METODE PEMBIASAAN DI TK AISYIYAH BUSTANUL ATHFAL 33 KOTA MALANG
}

\author{
Lailatul Machfiroh, Ellyn Sugeng Desyanty, Rezka Arina Rahmah \\ Jurusan Pendidikan Luar Sekolah \\ Universitas Negeri Malang \\ Jl. Semarang 5 Malang 65145 Jawa Timur Indonesia \\ ellyn.sugeng.fip@um.ac.id
}

\begin{abstract}
The Character is not born based on descent, but throughout the process of the character education which starts from early childhood. The phenomenon which occurs in ABA Kindergarten 33 is when the researcher come to the institute, the researcher see that the children can take a line behind their friends and accompanied by the teachers, thus the researcher interested to do the research about the formation of thedisciplin character in ABA 33 kindergarten through the habituation method. The purpose of the research is for: (1) to describe the process of the formation of the discipline character through the habituation methods in ABA 33 kindergarten; (2) to describe the behavior which showed by the children after they get the habituation; and (3) to find out the supporting and inhibitors factors in ABA 33 kindergarten. The research method which used by the researcher that is qualitative method. The research uses data collection technique, through observation, interview, documentation studies. The subject which are use in this research are teacher, cleanness employee, learners. There are three data analysis techniques which used that is: (1) data reduction; (2) data display; and (3) drawing conclusion.
\end{abstract}

\section{Keywords: character, discipline, and habituation method}

Abstrak: Hasil penelitian menunjukkan bahwa di TK Aisyiyah Bustanul athfal 33 melakukan pembentukan karakter disiplin melalui metode pembiasaan, hasil dari temuan penelitian tentang proses pembentukan karakter disiplin anak usia dini melalui metode pembiasaan adalah: (1) guru membiasakan anak untuk datang tepat waktu; (2) guru membiasakan anak untuk mengembalikan barang ke tempat semula; (3) guru membiasakan anak untuk membereskan mainan setelah bermain di dalam kelas; (4) guru membiasakan anak untuk bersabar dan tertib dalam menunggu giliran cuci tangan; dan (5) petugas kebersihan membiasakan anak untuk mengantri ketika ke kamar mandi. Pembiasaan yang dilakukan di TK Aisyiyah Bustanul Athfal 33 tidak hanya pembiasaan melalui ucapan atau kata motivasi saja, namun pembiasaan melalui perilaku juga dilakukan di TK Aisyiyah Bustanul Athfal 33, perilaku yang ditunjukkan oleh anak setelah mendapatkan pembiasaan dari guru yaitu: (1) anak datang tepat waktu, akan tetapi ada beberapa anak yang belum bisa datang tepat waktu, hal ini mengacu pada jumlah anak yang terlambat setiap hari mengalami naik turun; (2) anak mengembalikan barang yang telah digunakan pada tempatnya, hal ini ditunjukkan dengan kesadaran anak mengembalikan barang yang telah digunakan pada tempatnya tanpa diminta oleh guru, baik itu mainan ataupun alat tulis; (3) tertib dalam menunggu giliran, hal ini di tunjukkan dengan kesadaran anak berbaris di belakang temanya ketika cuci tangan tanpa didampingi oleh guru. Faktor pendukung pembentukan karakter disiplin di TK Aisyiyah Bustanul Athfal 33 yaitu adanya contoh dari pendidik, dan konsistensi yang dilakukan pendidik. Faktor yang menghambat pembentukan karakter disiplin di TK Aisyiyah Bustanul Athfal 33 yaitu ada beberapa orang tua yang tidak peduli dengan perkembangan anaknya,dan tidak adanya kerja sama antara orang tua dan sekolah, dan kematangan usia anak juga mempengaruhi pembentukan karakter disiplin anak usia dini di TK ABA 33.

Kata Kunci: Karakter, disiplin, metode pembiasaan

Pendidikan adalah usaha secara sadar untuk meningkatkan kualitas diri sendiri dari belum tahu menjadi tahu. Pada pasal satu dalam Undang-undang Sistem Pendidikan Nasional tahun (2003) menyatakan bahwa pendidikan adalah usaha sadar dan terencana untuk mewujudkan suasana belajar dan prosesnya agar peserta didik tersebut aktif dalam mengembangkan potensi dirinya. Jalur pendidikan merupakan wahana yang dilalui peserta didik untuk mengembangkan dirinya di dalam suatu proses pendidikan yang sesuai. Pendidikan formal merupakan jalur pendidikan yang terstruktur dan berjenjang dan terdiri dari pendidikan dasar, pendidikan menengah, dan pendidikan tinggi. Pendidikan formal sendiri kurikulum sudah ditentukan oleh pemerintah 
dan waktu dari pendidikan formal juga sudah terjadwal dengan rapi. Jalur pendidikan diluar pendidikan formal yang dapat dilaksanakan secara terstruktur dan berjenjang ini disebut dengan pendidikan nonformal, waktu pembelajaran dalam pendidikan nonformal ini bisa fleksibel dan bisa tersusun sesuai dengan kesepakatan peserta didik, namun ada juga yang sudah terstruktur dalam hal waktu pelaksanaan salah satu contohnya adalah PAUD.

Pendidikan anak usia dini dapat diselenggarakan melalui jalur pendidikan formal, nonformal, atau informal. Pendidikan anak usia dini pada jalur pendidikan formal adalah Taman Kanak-kanak, Raudatul Athfal atau bentuk lain yang sederajat. Sedangkan pendidikakan anak usia dini yang dilaksanakan di jalur pendidikan nonformal berbentuk Kelompok Bermain atau yang disingkat dengan KB, Taman Penitipan Anak atau TPA, atau bentuk lain yang sederajat. Pasal 1 angka 14 dalam Undang-undang Nomor 20 tahun (2003) tentang Sistem Pendidikan Nasional menyatakan bahwa pendidikan anak usia dini adalah upaya pembinaan yang ditujukan kepada anak sejak lahir sampai dengan usia enam tahun yang dilakukan melalui pemberian rangsangan pendidikan untuk membantu pertumbuhan dan perkembangan jasmani dan rohani agar anak memiliki kesiapan dalam memasuki pendidikan lebih lanjut

Pendidikan anak usia dini penting untuk anak, dikarenakan anak perlu diberikan stimulus pendidikan dan kesiapan untuk memasuki jenjang pendidikan dasar. Taman Kanak-kanak atau yang disingkat dengan TK merupakan salah satu jalur pendidikan formal yang di tempuh sebelum ke jenjang pendidikan dasar. Anak memasuki pendidikan TK ini pada usia 4-6 tahun. TK juga mempunyai tingkatan kelas, yaitu TK kecil yang biasa disebut dengan TK A dan TK besar yang biasa disebut dengan TK $B$.

Periode yang sangat penting dalam kehidupan manusia yang terjadi pada usia dini merupakan seluruh instrumen terbentuk, tidak hanya kecerdasan saja yang terbentuk tapi seluruh aspek perkembangan terbentuk pada usia golden age. Usia golden age terjadi pada usia 0-6 tahun. Masa-masa golden age merupakan masa terbaik dalam dalam proses belajar yang hanya sekali dan tidak akan terulang lagi. Pertumbuhan dan perkembangan anak pada masa ini berlangsung sangat cepat dan akan menjadi penentu bagi sifat atau karakter anak di masa dewasa. Pada anak usia dini, anak belajar melalui mengamati apa yang ada dan terjadi di sekitarnya, bukan hanya lewat nasihat tapi juga lewat perilaku.

Belajar itu bukan apa isi pembelajaran yang penting, melainkan bagaimana mempergunakan peralatan mental kita untuk menguasai hal hal yang kita pelajari. Menurut Semiawan (2008), Pengetahuan itu diciptakan kembali dan di bangun dari dalam diri seseorang melalui pengalaman, pengamatan,pencernaan dan pemahamannya. Penekanan tidak lagi seharusnya pada kuantitas materi, melainkan pada upaya agar anak usia dini menggunakan mentalnya secara efektif dan efisien sehingga tidak ditandai oleh segi kognitif belaka,melainkan keterlibatan emosi dan kemampuan kreatif pada anak.

Karakter tidak lahir berdasarkan keturunan atau terjadi tiba-tiba, akan tetapi membutuhkan proses melalui pendidikan karakter yang sudah di mulai sejak anak usia dini. Menurut Wynne dalam Jihad dkk (2010), karakter berasal dari bahasa yunani yaitu dari kata to mark yang berarti menandai dan memfokuskan pada pengaplikasian nilai kebaikan dalam bentuk perilaku atau tindakan seseorang. Karakter manusia berupa kebebasan dan kemampuan untuk memilih dan selanjutnya melakukan atau meninggalkan. Kebebasan berkehendak bagi setiap anak didik akan dapat menumbuhkan daya kreativitas sekaligus sebagai bekal untuk memperoleh kemampuan yang produktif. Pendidikan juga di peroleh ketika di lembaga tersebut, karena pendidikan itu berlangsung sepanjang hayat. Kreativitas pada diri anak dapat terwujud dengan memainkan peranan yang aktif yaitu selalu mengadakan aksi dan 
reaksi yang sesuai dengan lingkungan hidupnya.

Karakter sebagai sebuah proses yang dikehendaki, karakter sendiri mengajak peserta didik untuk mengenali keterbatasan diri, potensi-potensi, serta kemungkinankemungkinan bagi perkembangan peserta didik. Karakter merupakan ciri khas setiap individu berkenaan dengan jati dirinya, cara berfikir, dan cara berperilaku peserta didik. Menurut Prasetyo (2011), proses membangun karakter pada anak juga ibarat mengukir atau memahat jiwa sedemikian rupa sehingga berbentuk unik, menarik, dan berbeda antara satu dengan yang lain. Namun, seringkali orang tua tidak tahu akan hal itu dan sering membandingkan anaknya dengan anak tetangga.

Aulina (2013), berpendapat bahwa disiplin berasal dari kata yang sama dengan "disciple" dimana sesorang belajar secara suka rela mengikuti seorang pemimpin. orang tua dan guru sebagai pemimpin dan anak sebagai murid yang belajar cara hidup menuju kehidupan yang berguna dan bahagia. Jadi disiplin merupajan cara masyarakat mengajarkan anak berperilaku moral yang di setujui oleh kelompok.

Disiplin berbeda dengan hukuman pada dasarnya disiplin merupakan kebutuhan mutlak dimasa kanak-kanak (Aulina:2013). Masa ini merupakan masa yang paling efektif untuk pembentukan perliaku anak. Melalui disiplin anak belajar berperilaku sesuai dengan kondisi di sekolah maupun di lingkungan sekitar. Sedangkan hukuman merupakan salah satu unsur kedisiplinan yang diperlukan untuk mendisiplinkan anak. Hukuman sebagai bentuk konsekuensi pelanggaran yang dilakukan secara sengaja. Berikut ini merupakan hasil studi fenomena yang dilakukan oleh Laila (2017) yaitu mengajarkan disiplin kepada 25 anak usia dini memiliki tantangan tersendiri. Perlu cara menyenangkan, bermain dan bernyanyi. Seperti yang terjadi di TK Darma Wanita 3 Malang,

Berdasarkan latar belakang yang sudah dipaparkan di atas maka peneliti mengambil fokus penelitian sebagai berikut:
Bagaimana proses pembentukan karakter disiplin pada anak usia dini melalui metode pembiasaan di TK Aisyiyah Bustanul Athfal 33, (2) Bagaimana perilaku disiplin yang ditunjukkan oleh anak usia dini setelah mendapatkan pembiasaan di TK Aisyiyah Bustanul Athfal 33, (3)Apa faktor pendukung dan faktor penghambat dalam pembentukan karakter disiplin anak usia dini di TK Aisyiyah Bustanul Athfal 3. Tujuan dari penelitian ini adalah (1)Untuk mendeskripsikan proses pembentukan karakter disiplin pada anak usia dini di TK Aisyiyah Bustanul Athfal 33, (2) Untuk mendeskripsikan perilaku disiplin yang ditunjukkan oleh anak ketika sudah mendapatkan pembiasaan, (3)Untuk mengetahui faktor pendukung dan faktor penghambat dalam pembentukan karakter disiplin anak usia dini di TK Aisyiyah Bustanul Athfal 33.

Pendidikan anak usia dini atau yang biasa disingkat menjadi PAUD merupakan jenjang pendidikan sebelum pendidikan dasar, pendidikan anak usia din in diberikan ketika anak masih berusia 0-6 tahun melalui beberapa satuan yang ada di PAUD. Pendidikan anak usia dini dilakukan dengan cara pemberian berbagi rangsangan untuk membantu pertumbuhan dan perkembangan anak tersebut. Menurut Susanto (2017), tujuan dari pendidikan anak usia dini itu sendiri adalah mengembangkan pengetahuan dan pemahaman orang-orang di sekitar khususnya orang tua, guru, keluarga dll tentang bagaimana pendidikan dan perkembangan bagi anak. yang dimaksud dengan mengembangkan pengetahuan dan pemahaman orang disekitar adalah guru atau orang tua akan ditunjukkan bagaimana perkembangan anak dan tahap-tahap perkembangannya, orang disekitar juga dapat mengetahui bagaimana cara mengembangkan potensi-potensi yang muncul pada anak tersebut. Pendidikan anak usia dini memegang peranan sangat penting dalam bidang pendidikan, dikarenakan pendidikan anak usia dini merupakan fondasi dasar bagi kepribadian anak dan anak merupakan generasi penerus bangsa. Jadi perlu 
dipersiapkan sedini mungkin agar menjadi sumber daya manusia yang berkualitas. Pendidikan anak usia dini dijadikan sebagai cermin untuk melihat keberhasilan anak di masa mendatang.

Menurut Rahman (2002), pendidikan anak usia dini merupakan upaya yang direncanakan dan sistematis yang dilakukan oleh pendidik agar anak mampu mengembangkan potensi yang dimiliki, anak usia dini adalah anak yang berusia 0-8 tahun. Perbedaan sering kali muncul diantara para ahli. Akan tetapi pemerintah sudah menentukan usia anak usia dini pada Undangundang Republik Indonesia tentang Sistem Pendidikan Nasional Nomor 20 tahun 2003, yaitu ketika anak berusia 0-6 tahun. Peraturan Pemerintah Kementerian Pendidikan dan Kebudayaan Nomor 146 tahun 2014 menegaskan PAUD di selenggarakan berdasarkan kelompok usia dan jenis layanannya. Untuk anak yang baru saja lahir sampai dengan umur enam tahun terdiri dari taman penitipan anak atau yang biasa disebut dengan TPA atau Day Care, satuan paud sejenis atau SPS. Usia dua sampai empat tahun terdiri dari TK /RA/Bustanul Athfal.

Menurut Susanto (2017), "ada lima fungsi pendidikan anak usia dini, yaitu pengembangan potensi anak, penanaman dasar-dasar akidah dan keimanan, pembentukan dan pembiasaan perilaku yang diharapkan, pengembangan pengetahuan keterampilan dasar yang diperlukan, serta pengembangan motivasi yang positif". Penyelenggaraan pendidikan anak usia dini melalui tiga jalur yaitu jalur formal, non formal dan informal.

Pendidikan karakter merupakam pendidikan yang penting dan bisa diterapkan melalui beberapa metode, salah satunya yaitu metode pembiasaan. Menurut Gunawan (2012), metode pembiasaan dikenal dengan teori operant conditioning yang membiasakan perilaku terpuji, disiplin, giat belajar, bekerja keras dan ikhlas, jujur dan tanggung jawab atas segala tugas yang telah dilakukan. Metode pembiasaan ini merupakan sebuah cara yang digunakan dalam pembentukan karakter melalui pengulangan anak bertindak, berpikir dan bersikap sesuai dengan norma yang berlaku. Sependapat dengan Gunawan (2012), pembiasaan merupakan sesuatu yang sengaja di lakukan secara berulang-ulang agar sesuatu itu menjadi kebiasaan.

Menurut Fadlillah (2013), metode pembiasaan efektif dalam pembinaan sikap dikarenakan akan melatih kebiasaankebiasaan yang baik sejak anak usia dini. Menurut Mulyasa (2011), pendidikan dengan pembiasaan dapat dilaksanakan secara terprogram dalam pembelajaran atau dengan tidak terprogram dalam kegiatan sehari-hari. Kegiatan pembiasaan peserta didik yang dilakukan secara tidak terprogram dapat dilaksanakn dengan kegiatan rutin dan kegiatan dengan keteladanan, yang dimaksud dengan kegiatan rutin adalah pembiasaan yang dilakukan secara terjadwal contohnya sholat dhuha bersama, senam, memelihara kebersihan diri dan lingkungan sekolah dan lain-lain. kegiatan dengan keteladanan merupakan pembiasaan dalam bentuk perilaku sehari-hari contohnya berpakaian rapi, rajin membaca, memuji kebaikan atau keberhasilan orang lain, datang tepat waktu dan lain-lain.

Pembiasaan dalam penelitian ini tidak hanya dengan pembiasaan perilaku, tapi juga pembiasaan melalui ucapan dan juga pembiasaan melalui pengertian-pengertian yang diberikan oleh guru tersebut, pembiasaan-pembiasaan tersebut perlu dilakukan, sehingga keseimbangan antara 3 aspek pendidikan karakter itu tidak berat sebelah. Karena 3 aspek tersebut harus seimbang. Disetiap metode pasti ada kelebihan dan kekurangan. Kelebihan dari metode pembiasaan ini menurut adalah dapat menghemat tenaga dan waktu, kekurangan dari metode ini adalah membutuhkan kesabaran dan harus menstimulus anak tersebut supaya anak dapat melakukan kebiasaan baiknya.

Menurut Wynne istilah karakter ini erat dengan kepribadian seseorang, apabila kepribadian seseorang itu baik dan sesuai dengan otonomi yang berlaku di sekitar maka orang tersebut dikatakan orang yang 
berkarakter. Karakter merupakan susunan antropologis manusia, tempat dimana manusia menghayati kebebasannya dan mengatasi keterbatasan dirinya.

$$
\text { Menurut Lickona dalam (Wibowo, }
$$

2012) menjelaskan bahwa karakter merupakan sifat alami seseorang dalam merespons situasi secara bermoral. Lickona juga menyatakan bahwa ada 3 aspek pendidikan karakter dan tiga aspek ini harus berjalan seimbang, tanpa harus mengedepankan salah satu aspek. Tiga aspek pendidikan karakter yaitu moral knowing, moral feeling, dan moral action. Karakter adalah cara berfikir dan berperilaku yang menjadi ciri khas tiap individu untuk hidup dan bekerja sama, baik dalam lingkup keluarga, masyarakat, bangsa dan negara (Suyanto:2010).

Menurut Widyahening (2016), "caracter education can be done trough teaching learning literary appreciation especially literary works which contains of caracter education". Karakter bangsa merupakan aspek penting yang menentukan kemajuan suatu bangsa. Karakter yang berkualitas perlu dibina sejak usia dini agar anak terbiasa berperilaku positif.

Direktorat Pembinaan Pendidikan Anak Usia Dini (2012) Pendidikan karakter adalah pendidikan yang melibatkan guru dan orang tua untuk menanamkan pengetahuan dan perilaku yang bernilai positif agar perilaku tersebut bisa di terapkan oleh anak hingga dewasa nantinya. Menurut Direktorat Pembinaan Pendidikan Anak Usia Dini (2012) "ada tujuh prinsip pendidikan karakter yang harus dilaksanakan oleh pendidik dan lembaga PAUD, yaitu: (1)Melalui contoh dan keteladanan, (2)Dilakukan secara berkelanjutan, (3)Menyeluruh, terintegrasi dalam seluruh aspek perkembangan, (4)Menciptakan suasana kasih sayang, (5)Aktif memotivasi anak, (6)Melibatkan pendidikan dan tenaga kependidikan, orang tua, dan masyarakat, (7)Adanya penilaian.

Pembentukan karakter seyogyanya dilaksanakan sesuai dengan tahapan perkembangan anak dan berkelanjutan hingga memasuki usia dewasa. Penanaman karakter juga tidak seharusnya dilakukan hanya untuk satu aspek perkembangan saja, namun juga harus di tanamkan untuk semua aspek perkembangan. Kekerasan pada anak sangat tidak dibenarkan adanya, karena kekerasan pada anak akan mengganggu perkembangan anak, oleh karena pendidik dan lembaga PAUD harus menciptakan suasana yang nyaman, menyenangkan dan enuh dengan kasih sayang.

Menurut Gunawan (2012), ada 2 faktor yang mempengaruhi pembentukan karakter yaitu faktor intern (dalam) dan faktor ekstern (luar). Di dalam faktor internal ada beberapa hal yang mempengaruhi yaitu insting, kebiasaan, kehendak atau kemauan, suara hati, dan keturunan. Sedangkan yang faktor ekstern ada juga yang mempengaruhi yaitu pendidikan, dan lingkungan. Pendidikan karakter di sekolah menurut Wibowo (2012), baru menyentuh pada tingkatan pengenalan norma, dan belum mencapai pada tingkatan internalisasi dan tindakan nyata dalam kehidupan sehari-hari, namun pada tahun 2018 ini pendidikan karakter sudah mulai banyak di terapkan di sekolah-sekolah dari tingkat yang rendah hingga tingkat perguruan tinggi.

Karakter harus menjadi fondasi bagi kecerdasan dan pengetahuan. Jihad dkk (2010), menyatakan karakter adalah sesuatu yang bisa dibangun melalui proses dan salah satu cara untuk membangun karakter adalah dengan disiplin. Pembentukan karakter ini sangat penting dan mendesak, dikarenakan adanya krisis pendidikan karakter yang terus melanda negara Indonesia. Reformasi pendidikan sangat mutlak diperlukan untuk membangun karakter bangsa. Karena melalui pendidikan bisa meminimalisir krisis karakter di Indonesia.

Menurut Aulina (2013), disiplin merupakan suatu cara untuk mengajarkan anak atau seseorang mengenai perilaku moral yang berlaku di lingkungan anak tersebut, dan perlu unsur kesukarelaan dari dalam diri anak untuk mentaati sebuah peraturan yang berlaku. Menurut Schaefer dalam Aulina (2013), disiplin merupakan suatu hal yang dilakukan oleh orang dewasa yang mencakup 
pengajaran, bimbingan atau dorongan dan bertujuan untuk menolong anak belajar untuk hidup sebagai makhkuk sosial dan untuk mencapai pertumbuhan dan perkembangan anak secara optimal.

Penanaman karakter disiplin sejak dini merupakan hal penting yang harus dilakukan oleh para orang tua. Karena karakter disiplin merupakan karakter yang nantinya akan bermanfaat sepanjang hidupnya. Tujuan dari karakter disiplin adalah membentuk perilaku sedemikian rupa sehingga ia akan sesuai dengan peran-peran yang di tetapkan oleh sebuah kelompok atau lingkungan dimana anak tersebut menjalani kehidupan, baik itu di lingkungan sekolah maupun di lingkungan masyarakat.

Ketika anak tersebut di tanamkan karakter disiplin sejak dini maka anak tersebut akan tertib mematuhi dan menta'ati sebuah peraturan yang berlaku dimanapun tempatnya. Peraturan dapat dibuat secara fleksibel akan tetapi tegas, peraturan harus menyesuaikan dengan kondisi perkembangan anak, dan dilaksanakan dengan sifat yang tegas.

Pendidikan kedisiplinan perlu di terapkan pada anak karena ketika membuat kesalahan pasti ada resikonya. Dari sini anak bisa tahu mana yang benar dan mana yang salah, mana yang boleh dilakukan dan mana yang tidak boleh dilakukan. Bentuk-bentuk kegiatan disiplin ini harus dilakukan secara sukarela dan melalui pembiasaan dan keteladanan yang dilakukan oleh guru, masyarakat, dan orang tua, karena merekalah yang sangat berperan dalam pembentukan karakter disiplin. Penanaman disiplin tidak harus dengan cara kekerasan. Pemahaman para orang tua, guru, dan masyarakat yang kurang baik mengenai pengertia disiplin dapat memunculkan kasus-kasus yang terjadi pada anak. pemahaman yang bias dan tidak tepat mengenai pengertian disiplin dapat menimbulkan efek yang besar terhadap perkembangan anak. apabila anak tersebut tumbuh dan berkembang di lingkungan keluarga yang pemahamannya kurang tentang konsep disiplin maka tidak memungkiri terjadinya praktek kekerasan pada anak.
Menurut direktorat jenderal pendidikan anak usia dini, nonformal, dan informal kementrian pendidikan nasional tahun (2012) menjelaskan tentang tujuh indikator nilainilai karakter disiplin anak usia dini diantara lain: (1)Selalu datang tepat waktu, (2)Dapat memperkirakan waktu yang diperlukan untuk menyelesaikan sesuatu, (3)Menggunakan benda sesuai dengan fungsinya, (4)Mengambil dan mengembalikan benda pada tempatnya, (5)Berusaha mentaati aturan yang telah disepakati, (6)Tertib menunggu giliran, (7)Menyadari akibat bila tidak disiplin.

Selalu datang tepat waktu merupakan hal yang positif yang perlu ditanamkan sejak dini, disini orang tua dan guru juga sangat berperan karena ketika disekolah anak sudah di ajarkan tentang kedisiplinan maka secara otomatis orang tua pun juga harus menerapkan hal tersebut ketika dirumah. Ketika anak berangkat ke sekolah anak harus tiba di sekolah tersebut tepat waktu, disini orang tua dituntut untuk mengantarkan anak dan tiba tepat waktu. Di dalam pembentukan karakter disiplin ini perlu adanya pembiasaan yang dilakukan untuk melatih anak dalam penanaman disiplin, Tertib menunggu giliran salah satunya, tertib menunggu giliran adalah anak dilatih untuk bersabar dalam mengantri, baik itu ketika mandi, belajar, bermain dan lain-lain.

Disiplin merupakan salah satu karakter yang perlu ditanamkan sejak dini. Fadlilah (2013), berpendapat bahwa disiplin merupakan suatu tindakan yang dilakukan oleh anak dan menunjukkan perilaku tertib dan patuh pada berbagai peraturan yang sudah disepakati. Tujuan disiplin menurut Direktorat Pembinaan Pendidikan Anak Usia Dini (2011), ialah membuat anak didik tersebut terkontrol dalam menjalankan sebuah kegiatan. Tujuan dari disiplin itu tidak akan berhasil, apabila tidak dibarengi dengan usaha yang dilakukan oleh guru ataupun 
orang tua baik itu melalui pembiasaan ataupun melalui keteladanan.

Disiplin yang diterapkan pada anak merupakan salah satu nilai karakter pada anak usia dini, ketika anak sudah dapat disiplin anak tersebut akan dapat mengarahkan dirinya sendiri tanpa pengaruh dari orang yang ada disekitar. Orang tua dan guru dalam hal ini harus terus menerus melakukan pembiasaan atau keteladanan setiap hari, agar nilai-nilai kedisiplinan pada anak tidak gampang luntur dari diri anak.

Manfaat yang diharapkan dari penelitian ini diklasifikasikan menjadi dua yaitu manfaat teoritis dan manfaat praktis, berikut penjabaran manfaat teoritis dan praktis. Manfaat teoritis dari penelitian ini adalah Untuk mengetahui bagaimana pembiasaan yang di lakukan untuk membentuk karakter disiplin oleh pendidik. Sedangkan untuk manfaat praktis dari penelitian ini adalah (1)Bagi peneliti: penelitian ini bermanfaat untuk meningkatkan ketajaman berfikir dan kepekaan terhadap pembiasaan yang dilakukan untuk pembentukan karakter disiplin, penelitian ini juga bermanfaat sebagai salah satu syarat kelulusan di Universitas Negeri Malang, (2) Bagi guru dan petugas kebersihan sekolah: hasil penelitian ini dapat dimanfaatkan sebagai bahan acuan untuk pengembangan di TK ABA 33, (3) Bagi peneliti lain: sebagai tambahan referensi yang dapat digunakan dalam penelitian yang akan dilakukan dengan tema pembentukan karakter disiplin.

Ruang lingkup penelitian ini yaitu menjelaskan bagaimana proses pembentukan karakter disiplin di TK ABA 33, selain itu penelitian ini menjelaskan tentang perilaku yang ditunjukkan oleh anak setelah mendapatkan pembiasaan, dan faktorfaktor yang mempengaruhi dan menghambat pembentukan karakter disiplin.

Batasan penelitian ini diperlukan agar peneliti lebih tefokus dan terarah. Mengingat permasalahan yang dibahas dalam penelitian ini dapat berkembang menjadi luas dan kompleks. Penelitian dilakukan dengan subjek peserta didik dan pendidik di 4 kelas yaitu 2 TK A dan 2 TK B, serta dapur di TK ABA 33. Peneliti akan melakukan penelitian tentang pembiasaan yang dilakukan oleh pendidik dan petugas kebersihan untuk membentuk karakter disiplin dalam hal datang tepat waktu, mengembalikan barang ke tempat semula, mengantri ketika mau ke kamar mandi, tertib dalam menuggu giliran cuci tangan, bermain di dalam kelas, dan penelti akan meneliti perilaku anak yang muncul setelah mendapatkan pembiasaan.

Metode pembiasaan dalam penelitian ini yang dilakukan oleh guru dan pembantu yaitu: (1)guru membiasakan anak untuk datang tepat waktu, (2) guru membiasakan anak untuk membereskan mainan setelah bermain di dalam kelas, (3)guru membiasakan anak untuk mengembalikan barang yang telah digunakan, (4)guru membiasakan anak untuk tertib dalam menunggu giliran cuci tangan, (5)petugas kebersihan membiasakan anak untuk tertib dalam menunggu giliran ke kamar mandi. Indikator nilai karakter disiplin anak usia dini yang digunakan oleh peneliti dalam penelitian ini adalah: (1)selalu datang tepat waktu, (2)mengambil dan mengembalikan benda pada tempatnya, (3)tertib menunggu giliran.

\section{METODE}

Pada penelitian ini peneliti menggunakan metode kualitatif, pemilihan metode kualitatif dikarenakan penelitian ini dilakukan dalam kondisi alamiah yaitu pembiasaan perilaku di TK ABA 33 . Menurut Koentjaraningrat yang dikutip oleh Ulfatin (2015), penelitian kualitatif adalah 
penelitian di bidang ilmu-ilmu sosial dengan aktivitas yang berdasarkan alamiah dalam pengumpulan,pengklasifikasian, dan penafsiran fakta dalam hubungannya antara fakta alam, masyarakat, kelakuan dan rohani manusia.

Rancangan penelitian ini adalah studi kasus dimana mengangkat kasus tentang pembiasaan perilaku untuk membentuk karakter disiplin melalui pengumpulan data yang rinci, mendalam, dan mencakup berbagai sumber informasi yang kaya dengan konteks. Penggunaan jenis penelitihan studi kasus dikarenakan penelitian ini berfokus kepada proses pembiasaan perilaku apa saja yang diterapkan di TK ABA 33 sampai bisa untuk membentuk karakter seorang anak.

Dalam penelitian pasti ada instrumen, instrumen yang digunakan di dalam penelitian ini adalah peneliti sendiri sebagai instrumen utama.

Peneliti hadir di lokasi ini menggunakan teknik pengumpulan data diantaranya adalah observasi, wawancara, studi dokumentasi untuk mengetahui pembentukan karakter disiplin anak melalui pembiasaan perilaku yang di terapkan setiap hari di TK ABA 33. Peneliti selain menjadi instrumen utama dalam penelitian ini, peneliti dalam penelitian ini juga berperan sebagai perancang, perencana, observer, pewawancara, dan dokumenter atau sesuai dengan teknik yang digunakan. Tempat penelitian dalam penelitian ini berada di TK Aisyiyah Bustanul Athfal 33 atau yang biasa disingkat dengan sebutan TK ABA 33. TK ABA 33 ini terletak di perumahan Griya Shanta blok K331, kota Malang, Jawa timur Indonesia. Peneliti memilih lokasi tersebut karena TK ABA 33 merupakan tempat pembiasaan untuk mendidik karakter disiplin anak.

Sumber data dalam penelitian ini dibagi menjadi dua yaitu sumber data primer dan sumber data sekunder. Sumber primer. Data primer dalam penelitian ini adalah guru, peserta didik, dan petugas kebersihan yang ada di TK ABA 33. Data sekunder dalam penelitian ini mengenai data dan dokumen pembentukan karakter anak usia dini melalui pembiasaan perilaku, selain itu buku yang dijadikan sumber oleh peneliti juga merupakan data sekunder dari penelitian ini. Wujud dari data sekunder ini adalah dokumen tentang profil TK ABA 33.

Teknik pengumpulan data dalam penelitian ini ada 3 yaitu wawancara, observasi, dan studi dokumentasi. Menurut Sugiyono (2018), teknik analisis data ini digunakan untuk menjawab rumusan masalah atau hipotesis penelitian. Menurut Miles dan Huberman dalam Ulfatin (2015), alur yang digunakan dalam analisis data adalah (1)Reduksi data, (2)penyajian data, (3)penarikan kesimpulan. Setelah analisis data dilakukan, peneliti melakukan pengujian keabsahan data. Pengujian keabsahan data ini dapat dilakukan melalui 2 cara yaitu uji kredibilitas dan triangulasi. Dalam penelitian ini peneliti melakukan 2 jenis triangulasi yaitu: (1)triangulasi metode, hal yang dilakukan dalam penelitian ini adalah dengan membandingkan hasil wawancara, observasi dengan isi suatu dokumen lainnya, (2)triangulasi sumber, hal yang dilakukan dalam penelitian ini adalah membandingkan hasil penelitian dari beberapa sumber.

\section{HASIL}

Hasil penelitian menunjukkan bahwa proses pembentukan karakter disiplin anak usia dini yaitu guru datang sebelum anak datang, guru berdiri di halaman sekolah untuk menyambut anak datang, guru meminta anak yang terlambat untuk duduk di gazebo sekolah, guru membiasakan anak untuk mengembalikan buku ngaji, majalah pembelajaran, dan alat tulis ketempat anak mengambil, Guru memberi motivasi anak untuk merapikan barang yang telah digunakan, Guru meminta anak untuk membereskan mainan melalui nyanyian, Guru ikut membereskan mainan sebagai contoh untuk anak, Guru memberi tahu anak bahwa yang sudah selesai boleh cuci tangan, Guru ikut keluar untuk menertibkam anak apabila ada yang menyerobot, Petugas kebersihan membiasakan anak untuk tertib dalam menunggu giliran. 
Perilaku yang ditunjukkan oleh anak usia dini setelah mendapatkan pembiasaan dari guru yaitu Jumlah anak yang terlambat dari hari per hari mengalami fase naik turun, Anak mengembalikan buku ummi ketika guru tidak meminta anak untuk mengembalikan, Anak mengembalikan alat tulis yang telah digunakan ke tempatnya ketika tanpa diminta oleh guru, Anak membereskan mainan yang telah digunakan mesipun masih harus di ingatkan apabila waktunya sudah habis, Anak berbaris dan mengantri di belakang temannya untuk cuci tangan, Anak saling mengingatkan ketika ada anak yang mau menyerobot, Anak duduk di tangga dapur untuk mengantri cuci tangan ketika petugas kebersihan membersihkan anak yang ada di dalam kamar mandi. Faktor yang mempengaruhi pembentukan karakter disiplin ada 2 yaitu pendukung dan penghambat. Faktor pendukung pembentukan karakter disiplin adalah konsisten dengan aturan yang telah disepakati, contoh dan ketauladanan yang baik dari guru dan orang yang dekat dengan anak, kerja sama antara orang tua dan guru, Kompeten dalam menegakkan disiplin, kurang adanya kerja sama antara pihak orang tua dengan pihak sekolah, kematangan usia anak, Tidak konsisten, Tidak ada contoh dari orang tua atau orang terdekat dengan anak.

\section{PEMBAHASAN}

Hasil dari temuan penelitian tentang proses pembentukan karakter disiplin anak usia dini melalui metode pembiasaan adalah (1) guru membiasakan anak untuk datang tepat waktu, (2) guru membiasakan anak untuk mengembalikan barang ke tempat semula, (3) guru membiasakan anak untuk membereskan mainan setelah bermain di dalam kelas, (4) guru membiasakan anak untuk bersabar dan tertib dalam menunggu giliran cuci tangan, (5) petugas kebersihan membiasakan anak untuk mengantri ketika ke kamar mandi. TK ABA 33 ini melakukan pembentukan karakter melalui metode pembiasaan, tidak hanya pembiasaan perilaku saja, akan tetapi pembiasaan melalui ucapan, dan melalui pembiasaan memberikan pengetahuan kepada anak bahwa hal ini boleh dilakukan atau tidak boleh di lakukan, guru juga memberi motivasi kepada anak untuk menjaga dan merawat barangnya sendiri.

pernyataan tersebut sesuai dengan Lickona dalan Wibowo (2012) bahwa ada 3 aspek pendidikan karakter yaitu moral knowing, moral feeling, dan moral action.

Temuan penelitian menunjukkan bahwa guru datang sebelum murid datang, guru berdiri di halaman untuk menyambut anak datang, dan ketika ada anak yang terlambat guru juga memberi tahu anak agar anak besok bisa datang lebih pagi, pernyataan tersebut sesuai dengan pendapat Chasanah (2017) yang menyatakan bahwa kegiatan yang dilaksanakan secara tepat waktu dan kontinyu akan menimbulkan suatu kebiasaan. Anak di biasakan oleh guru tidak hanya melalui ucapan, perilaku dan motivasi, akan tetapi peraturan untuk datang pada pukul 07:00 sudah tertulis di tata tertib TK ABA 33. pernyataan tersebut sesuai dengan pendapat Anoraga (2006) yang menjelaskan bahwa disiplin merupakan suatu sikap, perbuatan, untuk selalu mentaati peraturan. Pernyataan di atas juga sesuai dengan pendapat Berutu dkk (2018) bahwa penerapan tata tertib sekolah berguna untuk mencegah perilaku negatif yang tidak sesuai norma di lingkungan sekolah. Anak di beri motivasi melalui ceritacerita moral agar anak datang tepat waktu, sesuai dengan pendapat Francisca dan Sukmo (2015) yang menyatakan bahwa moral knowing adalah proses pembentukan karakter dimana peserta didik diberi pengetahuan dan pemahaman berupa motivasi untuk membentuk karakter disiplin. TK ABA 33 melakukan sesuatu ketika ada anak terlambat, anak tidak diberi hukuman akan tetapi duduk ketika berdo'a sebelum masuk kelas di pisah, anak yang datang sebelum pukul 07:00 duduk ketika berdo'a di teras, sedangkan anak yang datangnya setelah pukul 07:00 duduk ketika berdo'a di gazebo sekolah.

Temuan penelitian menunjukkan bahwa guru membiasakan anak untuk mengembalikan barang ke tempatnya melalui contoh yang diberikan oeh guru, ucapan dengan perintah, serta kata-kata motivasi untuk anak. pernyataan tersebut sesuai dengan 
pendapat Lickona (2015) yang mengatakan bahwa mendisiplinkan secara bijaksana dengan cara mengajarkan yang benar dan memotivasi anak untuk melakukan apa yang benar. Pembiasaan di TK ABA 33 dilakukan secara konsisten oleh pendidik yang di terapkan setiap harinya pada anak. Guru di TK ABA 33 juga memberikan cerita motivasi kepada anak untuk merapikan dan membereskan barang yang telah digunakan, guru juga sering memberi reward ke anak untuk memotivasi anak, reward yang diberikan tidak harus berupa barang akan tetapi biasa melalui cerita-cerita menarik tentang motivasi membereskan barang yang telah digunakan ke tempatnya.

$\begin{array}{lr}\text { Membiasakan anak } & \text { untuk } \\ \text { mengembalikan barang ke tempatnya } \\ \text { merupakan salah satu indikator } & \text { karakter } \\ \text { disiplin yang dibiasakan di TK ABA } & \text { 33. Hasil } \\ \text { wawancara yang dilakukan peneliti }\end{array}$ menunjukkan bahwa tidak hanya ucapan atau kata-kata saja namun juga melalui perilaku yang di contohkan oleh guru, dalam hal ini guru ikut membereskan mainan walaupun sedikit, hal ini bertujuan untuk memberi contoh ke anak agar membereskan mainan yang selesai digunakan. pernyataan tersebut sesuai dengan pendapat Wibowo (2012) yang menyatakan bahwa seni mendisiplinkan anak di antaranya memberikan aturan kepada anak, akan tetapi di imbangi dengan curahan kasih sayang yang lebih besar. Aturan bermain selalu di bacakan dan di ingatkan oleh guru ketika sebelum bermain, aturan bermain juga di tempel di dinding kelas, hal ini bertujuan untuk membiasakan agar disiplin dalam membereskan mainan yang telah digunakan. Anak dikenalkan aturan tentang bermain, anak juga di ajak untuk membuat kesepakatan aturan bermain. Guru di TK ABA 33 memperingatkan agar ketika waktu bermain sudah habis dan anak diminta untuk membereskan mainan yang telah digunakan. Selain mengingatkan anak tentang waktu bermain, guru juga membiasakan anak untuk membereskan mainan melalui lagu "beresberes". Dengan lagu beres-beres anak mampu membereskan mainan yang telah digunakan
Temuan penelitian menunjukkan bahwa guru membiasakan anak untuk tertib dalam menunggu giliran cuci tangan melalui pembiasaan ucapan, motivasi dan perilaku. Pernyataan tersebut sesuai dengan pendapat Purwanti dan Rahmawati (2017) yang menyatakan bahwa nilai pendidikan karkater yang perlu di terapkan pada anak usia dini salah satunya adalah disiplin dalam budaya antri. Pembiasaan melalui perilaku, guru ikut keluar untuk menertibkan antrian cuci tangan, tidak hanya guru saja yang memperingatkan untuk antri ketika cuci tangan, namun ada anak yang ikut menertibkan dan membilangi anak untuk tertib dalam menunggu giliran cuci tangan. pernyataan tersebut sesuai dengan Wibowo (2012) yang menyatakan bahwa salah satu aspek pendidikan karakter yaitu moral action atau tindakan tentang moral, yang di maksud dengan moral action adalah perilaku moral yang di tunjukkan setelah mendapatkan pendidikan karakter. pernyataan tersebut juga sesuai dengan pendapat Aulina (2013) berpendapat bahwa disiplin itu dimana seseorang belajar sukarela dan mengikuti seorang pemimpin.

Temuan penelitian menunjukkan bahwa petugas kebersihan juga ikut membiasakan anak agar tertib dalam menunggu giliran ketika ke kamar mandi. budaya mengantri juga diberlakukan oleh petugas kebersihan, pernyataan tersebut sesuai dengan pendapat Ratnasari (2017) yang mengatakan bahwa budaya antri merupakan wujud dari sikap dan perilaku yang menghargai waktu dan hak orang lain. tertib dan sabar harus di tanamkan sejak dini salah satunya menggunakan metode pembiasaan yang berkaitan langsung dengan pendidikan karakter. Pembiasaan udaya antri ini dilakukan untuk meningkatkan perkembangan sosial emosional anak. Data penelitian menunjukkan bahwa anak di minta oleh petugas kebersihan untuk mengantri ketika ada anak yang datang bergerombolan datang ke kamar mandi. Sikap sabar dalam menunggu giliran ini dapat di tingkatkan melalui anak yang datang terlebih dahulu datang ke kamar mandi. 
Perilaku anak yang di tunjukkan mengacu pada direktorat jenderal pendidikan anak usia dini, non formal, dan informal kementerian pendidikan nasional (2012) yang menjabarkan indikator nilai disiplin, dan indikator nilai disiplin ada 7, akan tetapi yang digunakan peneliti dalam penelitian ini ada 3 yaitu datang tepat waktu, mengambil dan mengembalikan benda pada tempatnya, dan tertib menunggu giliran.

Temuan penelitian menunjukkan bahwa anak dapat datang tepat waktu, sebagaimana di temukan data (O/KA3/02012019), (O/KB4/07012019), (O/KA4/08012019), (O/KB1/11012019), (O/KB1/14012019), jumlah anak yang terlambat dari hari per hari mengalami fase naik turun, angka paling banyak anak terlambat yaitu 6 anak. Studi dokumentasi aturan dan tata tertib menunjukkan bahwa peserta didik masuk pada pukul 07:00 WIB, secara otomatis guru datang sebelum pukul 07:00 WIB untuk memberi contoh kepada anak agar datang tepat waktu, hal ini dilakukan oleh guru setiap hari untuk membiasakan anak. Pernyataan tersebut sesuai dengan Fadlillah (2013) yang menyatakan bahwa metode pembiasaan efektif dalam pembinaan sikap dikarenakan akan melatih kebiasaan-kebiasaan yang baik sejak anak usia dini. Pernyataan di atas senada dengan pendapat Mulyasa (2011) yang berpendapat bahwa pendidikan dengan pembiasaan dapat dilaksanakan secara tidak terprogram dalam kegiatan sehari-hari. Perilaku datang tepat waktu ini di dapatkan oleh anak setelah mendapatkan pembiasaan melalui contoh yang di lakukan oleh guru. Pendidik sebagai model untuk anak yang selalu menjadi teladan bagi anak baik sikap, keilmuannya, tingkah lakunya, dan kebiasaan yang di lakukan oleh guru baik di dalam kelas maupun di luar kelas.

Temuan penelitian menunjukkan bahwa anak mengembalikan barang yang telah digunakan ke tempatnya tanpa di minta oleh guru, seperti anak yang mengembalikan buku ummi, majalah, alat tulis, dan mainan. anak yang selesai mengaji setelah mendapatkan pembiasaan dari guru anak mengembalikan buku ummi ke tempatnya, begitu juga dengan alat tulis dan majalah pembelajaran. Anak yang selesai bermain setelah mendapatkan pembiasaan dari guru, ketika diingatkan tentang waktu bermain sudah habis anak segera membereskan mainan yang telah digunakan dengan menyanyikan lagu beres-beres, lagu beresberes secara tidak langsung berisi perintah yang meminta anak untuk membereskan dan mengembalikan barang baik itu berupa mainan atau yang lainnya. Anak ketika ada di TK A sudah dibiasakan untuk membereskan dan mengembalikan barang ke tempat anak mengambil baik itu melalui ucapan, perilaku atau contoh yang diberikan oleh guru. Pernyataan tersebut sesuai dengan pendapat Nopriadi (2016) yang menyatakan bahwa tujuan dari metode pembiasaan agar peserta didik memperoleh sikap dan kebiasaan baru yang lebih tepat dan selaras dengan kebutuhan. Penanaman pembiasaan mulai dari usia dini akan bermanfaat bagi anak ketika bertumbuh dewasa, hal ini sengaja dilakukan untuk membentuk karakter disiplin mengembalikan barang ke tempatnya. Karakter disiplin dalam mengembalikan barang ke tempatnya tidak semata-mata ada dan muncul pada diri anak, akan tetapi membutuhkan proses untuk membentuk karakter disiplin dalam mengembalikan barang yang telah di gunakan. Pernyataan tersebut sesuai dengan pendapat Jihad dkk (2010) yang menyatakan bahwa karakter adalah suatu yang bisa dibangun melalui proeses.

Temuan penelitian menunjukkan bahwa perilaku yang ditunjukkan oleh anak setelah mendapatkan pembiasaan dari guru dalam hal tertib dalam mengantri yaitu anak dapat berbaris di belakang temannya untuk mengantri ketika cuci tangan tanpa didampingi oleh guru. Penyataan ini sesuai dengan pedoman pendidikan karakter pada pendidikan anak usia dini yang dikeluarkan oleh direktorat pembinaan pendidikan anak usia dini (2012) indikator nilai karakter disiplin yaitu tertib menunggu giliran. Menurut Mufidah (2012) kegiatan 
pembiasaan peserta didik yang dilakukan secara tidak terprogram dapat dilaksanakan dengan kegiatan rutin dan kegiatan dengan keteladanan, kegiatan rutin yang dilakukan secara terjadwal memelihara kebersihan diri dan lingkungan sekolah, sedangkan kegiatan pembiasaan yang dilakukan dengan keteladanan contohnya adalah datang tepat waktu, mengantri. peningkatan rasa sabar dalam menunggu giliran baik dalam cuci tangan maupun ke kamar mandi, dapat dilihat ketika guru dan petugas kebersihan membiasakan anak setiap hari. Data dalam penelitian ini menunjukkan bahwa strategi untuk meningkatkan kesabaran agar anak tertib dalam menunggu giliran yaitu dengan mendahulukan anak yang datang duluan ketika ke kamar mandi ataupun cuci tangan, atau dengan memberi tahu anak bahwa yang sudah selesai mengerjakan tugas yang diberikan boleh mencuci tangan. Peserta didik di TK ABA 33 diberi pengetahuan untuk sabar dalam menunggu giliran baik dalam cuci tangan maupun ke kamar mandi.

Pembentukan karakter disiplin anak usia dini dengan metode pembiasaan di TK ABA 33 memiliki berbagai pendukung baik dari faktor internal dan faktor eksternal, selain faktor pendukung pasti ada faktor penghambat faktor penghambat juga ada faktor internal dan faktor eksternal, hal ini sesuai dengan pendapat Gunawan (2012) ada 2 faktor yang mempengaruhi pembentukan karakter yaitu faktor internal dan faktor eksternal. Faktor pendukung merupakan faktor yang mempengaruhi dan mendorong pembentukan karakter disiplin di TK ABA 33. Faktor pendukung ini ada dari internal dan eksternal. Faktor pendukung internal dari pembentukan karakter disiplin di TK ABA 33 yaitu: (1) pendidik konsisten dengan apa yang telah dibiasakan kepada anak (2) pendidik dan peserta didik konsisten dengan aturan yang telah di sepakati (3) ada contoh atau keteladanan yang diberikan oleh guru (4) pendidik kompeten dalam menegakkan disiplin. Faktor eksternal yang mendukung pembentukan karakter disiplin di TK ABA 33 yaitu: (1) adanya kerja sama antara orang tua dan guru melalui komite sekolah ataupun langsung ke guru untuk menanyakan bagaimana anak di kelas hari tersebut. pernyataan tersebut sesuai dengan pendapat Lickona (2013) yang menyatakana bahwa ketika menegakkan disiplin harus melibatkan orang tua, jadi disiplin di sekolah dan di rumah sesuai. TK ABA 33 memiliki komite sekolah yang menjembatani hubungan orang tua dengan guru, selain melalui komite, melalui buku penghubung guru juga berkoordinasi dengan orang tua, ada juga orang tua yang langsung menanyakan ke guru ketika menjemput sekolah, tentang bagaimana perilaku anak di kelas, kadang juga guru yang memberi tahu ke orang tua yang menjemput anak apabila ada perilaku yang memang harus di contohkan dari orang tua. Pernyataan di atas tentang adanya contoh perilaku dari guru dan orang tua atau orang yang dekat dengan anak senada dengan pendapat Helmawati (2016) bahwa gaya bicara, ekspresi wajah, nada suara hingga gerak gerik atau perilaku orang tua, guru, orang yang terdekat dengan anak akan di perhatikan dan kemuadian di rekam dalam memori anak. Anak akan bertingakah laku megikuti apa yang dilakukan oleh orang di sekitar seperti guru, orang tua, pengasuh, dan lingkungan keluarga lainnya. Pembentukan karakter disiplin anak usia dini selain ada faktor pendukung pastnya ada faktor penghambat dalam hal tersebut. faktor penghambat merupakan faktor yang menghalangi atau memperlambat dalam suatu hal. Bukan hanya faktor pendukung saja yang mempunyai faktor internal dan faktor eksternal, akan tetapi faktor eksternal juga mempunyai faktor internal dan faktor eksternal. Faktor eksternal dari pembentukan karakter disiplin anak usia dini di TK ABA 33 yaitu: (1) tidak ada contoh dari orang tua, atau orang yang terdekat dengan anak contohnya seperti keluarga, (2) orang tua pasif akan perkembangan anak (3) ada orang tua yang tidak bekerja sama dengan sekolah. Faktor internal penghambat pembentukan karakter disiplin di TK ABA 33 yaitu (1) kematangan usia anak. kematangan usia anak juga berpengaruh pada pembentukan karakter karena pemberian stimulus harus sesuai dengan tahap tugas perkembangan. 
Pernyataan tersebut sesuai dengan pendapat Lickona (2013) yang menyatakan bahwa ketika menegakkan disiplin harus melibatkan orang tua atau orang yang terdekat dengan anak.

\section{KESIMPULAN}

Berdasarkan hasil penelitian tentang pembentukan karakter disiplin anak usia dini melalui metode pembiasaan (studi kasus di TK ABA 33) dapat di tarik kesimpulan bahwa proses pembentukan karakter disiplin melalui metde pembiasaan di TK ABA 33 yaitu guru sebagai model dan sebagai tauladan bagi anak, guru juga memberi contoh pada anak, memberi motivasi kepada anak, memberi pengertian kepada anak tentang mana yang boleh dilakukan dan mana yang tidak boleh dilakukan. Proses pembiasaan yang berlaku di TK ABA 33 pendidik tidak hanya melakukan pembiasaan melalui ucapan atau kata-kata motivasi saja, akan tetapi guru juga membiasakan lewat perilaku yang dilakukan oleh guru.

Perilaku yang ditunjukkan oleh anak setelah mendapatkan pembiasaan yaitu anak dapat datang tepat waktu meskipun ada beberapa anak yang terlambat dan anagka terlambat paling tinggi adalah 6 anak. Selain itu anak ketika mengambil barang atau mainan, anak mengembalikan barang ke tempatnya tanpa diminta oleh guru. Untuk perilaku yang di tunjukkan ketika membereskan mainan, anak membereskan mainan walaupun harus tetap diingatkan bahwa waktunya sudah habis. Perilaku yang ditunjukkan anak tertib dalam menunggu ketika cuci tangan yaitu anak berbaris di belakang temannya untuk mengantri, untuk perilaku yang ditunjukkan anak tertib dalam menunggu giliran ke kamar mandi yaitu anak duduk di tangga dapur untuk mengantri ketika petugas kebersihan membersihkan anak yang ada di dalam kamar mandi.

Faktor yang mempengaruhi pembentukan karakter ada 2 yaitu faktor pendukung dan faktor penghambat. Faktor pendukung pembentukan karakter disiplin di TK ABA 33 ini adanya konsistensi dari pihak guru untuk menegakkan disiplin, selain itu orang tua juga menjalin kerja sama dengan guru melalui organisasi komite sekolah. Faktor penghambat pembentukan karakter anak usia dini yaitu ada beberapa orang tua yang tidak mau ikut andil, cuek terhadap perkembangan anak. kematangan usia anak juga menjadi penghambat, karena apabila anak belum waktunya untuk di beri stimulus yang di terapkan pada pembelajaran, anak akan merespon akan tetapi lambat untuk merespon.

\section{SARAN}

Berdasarkan kesimpulan yang diperoleh dalam penelitian ini, maka diajukan saran-saran pada lembaga TK ABA 33 kota Malang, ada 2 saran untuk lembaga dan untuk komite sekolah: (1)Untuk lembaga TK ABA 33 untuk mengelompokkan anak sesuai usia anak agar tugas perkembangan anak sesuai dengan usia nya, dan bisa maksimal dalam perkembangan, sehubungan dengan hal ini pendidik perlu merangkul para orang tua yang tidak peduli akan perkembangan anaknya. Untuk pihak sekolah supaya melakukan penyuluhan tentang usia anak untuk masuk ke sekolah TK, agar orang tua tau berapa usia anak untk masuk ke TK. (2) Untuk komite sekolah agar bisa bekerja sama dengan guru secara maksimal untuk perkembangan anak, dan merangkul para orang tua yang tidak peduli dengan perkembangan anak.

\section{DAFTAR RUJUKAN}

Anoraga, Panji.2006. Psikologi Kerja.

Jakarta: PT.Rineka Cipta

Aulina, Choirunnisak.2013.Penanaman disiplin pada anak usia dini: Jurnal Pedagogia Vol.2 No.1

Berutu, Elfi Yati dkk. 2018. Implementasi

Tata Tertib Sekolah Dalam

Membentuk Kedisiplinan Siswa Sekolah Dasar Negeri Gue Gajah

Aceh Besar: Jurnal ilmiah pendidikan guru sekolah dasar FKIP Unsyiah Vol.3 No. 2

Chasanah, Nur. 2017. Upaya Mengatasi Keterlambatan Siswa Masuk Kelas Melalui Layanan Penguasaan Konten Dengan Teknik Manajemen Waktu: Jurnal Pedagogia Vol.4 No.2 
Direktorat pembinaan pendidikan anak usia dini, direktorat jenderal pendidikan anak usia dini, nonformal, dan informal.2012. Pedoman pendidikan karakter pada anak usia dini: Jakarta. Kementerian penddikan nasional.

Fadlillah, Muhammad, Khorida, Lilik mualifatu. 2013. Pendidikan karakter anak usia dini: Jogjakarta.Ar-ruzz.

Francisca, Leonie Sukmo, Aji clara.2015. Keterkaitan antara moral knowing, moral feeling, dan moral behavior pada empat kompetensi dasar guru: Jurnal kependidikan Vol.45 No.2

Gunawan, Heri.2012. pendidikan karakter konsep dan implementasi: Jakarta. PT. Bumi Aksara.

Jihad, Asep dkk.2010. pendidikan karakter teori dan

aplikasinya:Jakarta.Direktorat jenderal manajemen pendidikan dasar dan pendidikan menengah kementterian pendidikan nasional.

Laila, Arni Nur.2017. Jika siswa Taman Kanak-kanak belajar berlalu lintas, inilah yang diharapkan, (online) (http://surabaya.tribunnews.com/2017/ 01/16/jika-siswa-taman-kanak-kanakbelajar-berlalu-lintas-inilah-yangdiharapkan). Di akses 16 Januari 2017 pukul 19:26 WIB

Lickona, Thomas.2015. terjemahan Character Matters oleh Wamaungo dan Zien. Jakarta: Bumi Aksara.

Mufidah, Umri. 2012. Efektifitas Pemberian Reward Melalui Metode Token Ekonomi Untuk Meningkatkan Kedisiplinan Anak Usia Dini. Journal of early childood education papers. Vol.1 No.1

Nopriadi, Eko. 2016. Penerapan metode pembiasaan untuk menanamkan nilainilai pendidikan islam pada siswa SD Negeri 38 Janna-Jannayya kecamatan Sinoa kabupaten Bantaeng. Skripsi tidak diterbitkan. Makasar: Universitas Negeri Alauddin Makasar.
Prasetyo, Nana.2011. Membangun karakter anak usia dini: Direktorat pembinaan pendidikan anak usia dini, direktorat jenderal pendidikan anak usia dini nonformal dan informal, kementerian pendidikan dan kebudayaan

Rahman, Hilbana.2002. konsep dasar penddikan anak usia dini: Yogyakarta. Grafindo litera media

Rahmawati, Purwanti, \& Nur Ika Sari. 2017. Pembiasaan Budaya Antri Untuk Peningkatan Pengembangan Sosial Emosional Pada Anak Usia 3-4 Tahun Melalui Kegiatan Fun Game Di Ppt Mentari Pagi Surabaya. Jurnal paud teratai Vol. 6 No. 1

Ratnasari, Sukesi.2017. Pembiasaan Budaya Antri Untuk Peningkatan Pengembangan Sosial Emosional Pada Anak Usia Dini. Skripsi diterbitkan. Yogyakarta: Universitas Islam Negeri Sunan Kalijaga Yogyakarta.

Sugiyono. 2018. Metode Penelitian Kuantitatif, Kualitatif, dan $R \& D$ : Bandung. Alfabeta

Susanto, Ahmad. 2017. Pendidikan anak usia dini (konsep dan teori) : Jakarta. PT. Bumi aksara

Suyanto. 2010. Urgensi pendidikan karakter, www.mandikdasmen.depdiknas.go.id/ web/pages/urgensi.html.

Ulfatin, Nurul. 2015. Metode penelitian kualitatif dibidang pendidikan; teori dan aplikasinya. Malang. MNC publishing.

Wibowo, Agus.2012. pendidikan karakter anak usia dini (strategi membangun karakter di usia emas): Yogyakarta. Pustaka pelajar

Widyahening, Evy Tri,Wardhani, Nugraheni Eko.2016. Literary Works and Caracter Eduction. International journal of language and literature, 4(1). DOI: 10.15640/ijll.v4n1a2 